\title{
STUDIES ON EFFECTS OF FORPHENICINOL ON IMMUNE RESPONSES
}

\author{
Masaaki Ishizuka, SeiJi Ishizeki, Toru Masuda, Ayako Momose, \\ Takanki Aoyagi, Tomio Takeuchi and Hamao Umezawa \\ Institute of Microbial Chemistry \\ 14-23 Kamiosaki 3-chome, Shinagawa-ku, Tokyo 141, Japan
}

(Received for publication May 19, 1982)

\begin{abstract}
The oral administration of forphenicinol, S-2-(3-hydroxy-4-hydroxymethylphenyl)glycine which was synthesized during the study of derivatives and analogs of forphenicine, augmented delayed-type hypersensitivity to sheep red blood cells and oxazolone in mice. The treatment with forphenicinol restored DTH in mice immuno-suppressed by cyclophosphamide to normal response. Forphenicinol neither augmented antibody-formation nor stimulated proliferation of lymphocytes in the presence or absence of lectins. Phagocytosis by peritoneal macrophages was enhanced by forphenicinol in vivo and in vitro. Forphenicinol was effective in increasing the production of CFU-C in the presence of colony stimulating factor and partially prevented the reduction of leucocyte counts caused by mitomycin $\mathrm{C}$.
\end{abstract}

As we reported ${ }^{1)}$, the screening for inhibitors of enzymes which are located on cell surfaces or membranes resulted in the discovery of low molecular weight immuno-modifiers. In such a study, we found forphenicine, S-2-(4-formyl-3-hydroxyphenyl)glycine (Fig. 1) ${ }^{1 \sim 3)}$, which inhibited chicken intestine alkaline phosphatase and enhanced delayed-type hypersensitivity $(\mathrm{DTH})^{1)}$. Forphenicine also increased the number of antibody-forming cells and exhibited inhibition against some murine transplantable tumors ${ }^{1)}$. These effects in vivo were shown by intraperitoneal administration but not by oral administration. Therefore, we synthesized derivatives and analogs and found that forphenicinol, $S-2-(3-$ hydroxy-4-hydroxymethylphenyl)glycine, enhanced DTH and exhibited antitumor effect ${ }^{4)}$ by oral administration.

In this paper we will report on the action of

Fig. 1. Structures of forphenicine $(\mathrm{R}=\mathrm{CHO})$ and forphenicinol $\left(\mathrm{R}=\mathrm{CH}_{2} \mathrm{OH}\right)$.

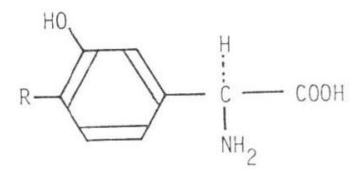
forphenicinol in augmenting immune responses.

\section{Materials and Methods}

Mice

$\overline{\mathrm{CDF}_{1}}$ mice $(\mathrm{Balb} / \mathrm{c} \times \mathrm{DBA} / 2$, female, $8 \sim 10$ weeks old) were purchased from Shizuoka Laboratory Animal Agriculture Cooperative Association, Shizuoka, Japan. They were kept under filtered fresh air at a constant room temperature of $23 \pm 1{ }^{\circ} \mathrm{C}$, relative humidity of $55 \pm 5 \%$, and fed sterilized mouse pellet (FR-1, Funabashi Farm Co. Ltd., Chiba) and water ad libitum.

Forphenicinol and Other Chemicals

Forphenicinol was chemically synthesized. The method of synthesis will be reported on the other paper ${ }^{5)}$. It was dissolved in saline or in culture medium. Cyclophosphamide ("Endoxan" Shionogi \& Co. Ltd.) and mitomycin C (Kyowa Hakko Co. Ltd.) were dissolved in saline. Concanavalin A (ConA, Pharmacia) and lipopolysaccharide (LPS, Difco Laboratories) were dissolved in culture medium at $0.5 \mu \mathrm{g} / \mathrm{ml}$ and $2 \mu \mathrm{g} / \mathrm{ml}$ respectively. 


\section{Immune Responses}

Delayed-type hypersensitivity (DTH) to sheep red blood cells (SRBC) or to oxazolone was tested by the method described previously ${ }^{6)}$. Forphenicinol was given to mice at the time of immunization.

Antibody formation to SRBC was measured by the hemolytic plaque technic ${ }^{7,8)} 4$ days after the immunization. Five mice were used in each group.

Blastogenesis of Mouse Spleen Cells

As reported previously for testing the effect of bestatin ${ }^{\theta, 10)}$, spleen cells were suspended in RPMI 1640 containing $1 \%$ fetal calf serum (Lot R. 393423, Gibco, N. Y.) and forphenicinol at the indicated concentrations, and cultured for 3 days in Falcon Microtest plate 3042. When the effect on lectin was tested, ConA or LPS was added at $0.5 \mu \mathrm{g} / \mathrm{ml}$ or at $2 \mu \mathrm{g} / \mathrm{ml}$ respectively. The incorporation of [ ${ }^{3} \mathrm{H}$ ]thymidine into cultured cells was determined by the method described previously ${ }^{9,10)}$. Triplicate cultures were done for each datum.

\section{Phagocytosis of Yeasts by Mouse Peritoneal Macrophages}

The effect of forphenicinol on phagocytosis by mouse peritoneal macrophages was tested by the method described for the study of bactobolin ${ }^{11}$. Mice were given forphenicinol orally and 18 hours later, thioglycolate-stimulated peritoneal exudate cells were collected; peritoneal exudate cells were incubated in a plastic dish for 2 hours and adherent cells were prepared; to adherent cells $0.05 \mathrm{ml}$ of yeast suspension $\left(7.5 \times 10^{8}\right.$ cells $\left./ \mathrm{ml}\right)$ was added and incubated for 45 minutes at $37^{\circ} \mathrm{C}$ in $50 \% \mathrm{CO}_{2}$ in air; after washing thoroughly, adherent cells on the bottom of the plates were stained with May-Grünwald and Giemsa solution and the number of phagocytic cells were counted. Triplicate cultures were done for each datum.

\section{Production of Colony-forming Cells by Bone Marrow Cells In Vitro}

Bone marrow stem cells were cultured with colony-stimulating factor (CSF) and the colony-forming unit in culture (CFU-C) was counted by the method reported previously ${ }^{11}$, based on the method described by MetCAlF ${ }^{12)}$, and StAnley et al. ${ }^{13)}$ LPS-induced mice serum was used as CSF ${ }^{12)}$. Forphenicinol was dissolved in $0.05 \mathrm{ml}$ and added at the start of the culture.

Determination of Leucocyte Counts in Mouse Peripheral Blood

After treatment with mitomycin C (50 $\mathrm{g} /$ mouse, daily, i.p.) with or without forphenicinol (10 $\mu \mathrm{g} /$ mouse, daily, p.o.) for 5 days, $20 \mu$ l of venous blood was taken from the orbital vein by puncture using a sterile glass capillary tube at the day indicated in Fig. 3. The blood was diluted with Isoton containing Zap-Oglobin (Coulter Diagnostics) and leucocytes were counted by a Coulter Counter.

\section{Results}

\section{Effect of Forphenicinol on DTH}

The effect of forphenicinol on cell-mediated immunity was examined by testing its effect on DTH to SRBC and to oxazolone.

Mice were immunized by subcutaneous injection of $10^{8}$ SRBC into footpad and were given forphenicinol orally or intraperitoneally. Four days after immunization, DTH response was elicited by subcutaneous injection of $10^{8} \mathrm{SRBC}$ to the footpad of the other side and 24 hours later, the footpad thickness was measured. As shown in Table 1, in both routes of the administration, forphenicinol augmented the DTH response. Compared to the intraperitoneal route, the oral administration was more effective. The enhancement was caused by 1,10 and $100 \mu \mathrm{g} /$ mouse orally.

Forphenicinol also augmented oxazolone-induced DTH. As shown in Table 2, the oral administration of from $1 \mu \mathrm{g}$ to $1 \mathrm{mg} / \mathrm{mouse}$ augmented the response.

The effect of forphenicinol in immuno-suppressed mice was examined. Mice were given $6 \mathrm{mg} /$ mouse of cyclophosphamide intravenously once and forphenicinol daily for 3 days. After the treat- 
Table 1. Effect of forphenicinol on the establishment of delayed-type hypersensitivity to sheep red blood cells.*

\begin{tabular}{|c|c|c|c|c|c|}
\hline \multirow{2}{*}{$\begin{array}{l}\text { Immunization } \\
10^{8} \mathrm{SRBC}\end{array}$} & \multirow[t]{2}{*}{$\begin{array}{l}\text { Forphenicinol } \\
\text { ( } \mu \mathrm{g} / \text { mouse) }\end{array}$} & \multicolumn{2}{|c|}{$\begin{array}{c}\text { I.p. } \\
\text { Increase of footpad thickness } \\
(\times 0.1 \mathrm{~mm} \pm \text { S.D. })\end{array}$} & \multicolumn{2}{|c|}{$\begin{array}{c}\text { P.o. } \\
\text { Increase of footpad thickness } \\
(\times 0.1 \mathrm{~mm} \pm \text { S.D. })\end{array}$} \\
\hline & & $7.7 \pm 2.1$ & & $7.9 \pm 2.1$ & \\
\hline$"$ & 1,000 & $7.0 \pm 1.5$ & & $10.3 \pm 2.9$ & \\
\hline$n$ & 100 & $9.3 \pm 3.7$ & & $12.5 \pm 1.6$ & $\mathrm{P}<0.01$ \\
\hline$n$ & 10 & $10.5 \pm 4.5$ & & $12.6 \pm 2.1$ & $\mathrm{P}<0.05$ \\
\hline$n$ & 1 & $11.3 \pm 2.9$ & $\mathrm{P}<0.05$ & $13.7 \pm 2.4$ & $\mathrm{P}<0.05$ \\
\hline$n$ & 0.1 & $13.0 \pm 2.5$ & $\mathrm{P}<0.05$ & $9.9 \pm 1.0$ & \\
\hline
\end{tabular}

* $\mathrm{CDF}_{1}$ mice ( 8 weeks old, female) were immunized with $10^{8} \mathrm{SRBC}$ by subcutaneous injection to right footpad of hind paw and administered each dose of forphenicinol i.p. or p.o. Four days later, mice were challenged with $10^{3} \mathrm{SRBC}$ s.c. to left footpad, 24 hours thereafter, the thickness of resulting edema on left footpad was measured by calipers.

Table 2. Effect of forphenicinol on the establishment of delayed-cutaneous hypersensitivity to oxazolone.*

\begin{tabular}{cc|c}
\hline Immunization & $\begin{array}{c}\text { Forphenicinol } \\
(\mu \mathrm{g} / \text { mouse, p.o. })\end{array}$ & $\begin{array}{c}\text { Increase of } \\
\text { footpad thickness } \\
(\times 0.1 \mathrm{~mm} \pm \mathrm{S} . \mathrm{D} .)\end{array}$ \\
\hline Oxazolone & - & $3.5 \pm 0.11$ \\
\hline$"$ & 1,000 & $5.4 \pm 0.14 \mathrm{P}<0.01$ \\
\hline$"$ & 100 & $5.2 \pm 0.05 \mathrm{P}<0.01$ \\
$"$ " & 10 & $5.3 \pm 0.01 \mathrm{P}<0.01$ \\
$"$ " & 1 & $6.2 \pm 0.06 \mathrm{P}<0.01$ \\
\hline
\end{tabular}

* $\mathrm{CDF}_{1}$ mice (male, 10 weeks old) were immunized by painting $0.1 \mathrm{ml}$ of $5 \%$ oxazolone - ethanol solution on shaved abdomen and administered forphenicinol orally. Two days later, oxazolone was painted on left footpad of hind paw and 48 hours thereafter, the thickness of left hind paw was measured by calipers. ment, mice were immunized by subcutaneous injection of $10^{8} \mathrm{SRBC}$ into the footpad and the DTH response was tested. As shown in Table 3, DTH was strongly suppressed by cyclophosphamide treatment. Daily administration of forphenicinol $100 \mu \mathrm{g} /$ mouse prevented this suppression and restored DTH to an almost normal level. Treatment with $10 \mu \mathrm{g} /$ mouse showed partial restoration and no effect was obtained with $1 \mu \mathrm{g} /$ mouse.

Influence of Forphenicinol on Antibody Formation to SRBC

The influence of forphenicinol on antibody formation was tested by the hemolytic plaque technique. Mice were immunized by intravenous

Table 3. Effect of forphenicinol on the establishment of delayed-type hypersensitivity to sheep red blood cells in mice immuno-suppressed by cyclophosphamide (CY).*

\begin{tabular}{|c|c|c|c|c|c|c|}
\hline \multicolumn{4}{|c|}{ Treatment } & \multirow{2}{*}{$\begin{array}{l}\text { Immunization } \\
\text { day } 0\end{array}$} & \multirow{2}{*}{\multicolumn{2}{|c|}{$\begin{array}{c}\text { Increase of } \\
\text { footpad thickness } \\
(\times 0.1 \mathrm{~mm} \pm \text { S.D. })\end{array}$}} \\
\hline day -4 & \multicolumn{3}{|c|}{ day $-3 \sim-1$} & & & \\
\hline CY $6 \mathrm{mg} /$ mouse, i.v. & \multicolumn{3}{|c|}{ - } & $10^{8} \mathrm{SRBC}$ & $1.2 \pm 0.13$ & \\
\hline$n$ & Forphenicinol & \multicolumn{2}{|c|}{$100 \mu \mathrm{g} /$ mouse } & $"$ & $9.4 \pm 0.58$ & $\mathbf{P}<0.01$ \\
\hline " & " & 10 & $" \prime$ & " & $6.5 \pm 1.6$ & $\mathrm{P}<0.05$ \\
\hline " & " & 1 & $n$ & $"$ & $1.1 \pm 0.10$ & \\
\hline None & \multicolumn{3}{|c|}{ - } & $10^{8} \mathrm{SRBC}$ & $9.5 \pm 0.04$ & \\
\hline
\end{tabular}

* $\mathrm{CDF}_{1}$ mice (female, 8 weeks old) were injected $6 \mathrm{mg} / \mathrm{mouse}$ of cyclophosphamide (CY, Endoxan, Shionogi) intravenously, and 1 day later, they were given $100 \mu \mathrm{g}$ to $1 \mu \mathrm{g} /$ mouse of forphenicinol orally once a day for 3 consecutive days. One day after the last administration, mice were immunized with $10^{8}$ SRBC and DTH response was determined as described in Table 1. 
Fig. 2. Effect of forphenicinol on phagocytosis of yeasts by peritoneal macrophages.

Forphenicinol was given p.o. to $\mathrm{CDF}_{1}$ mice 24 hours before assay.

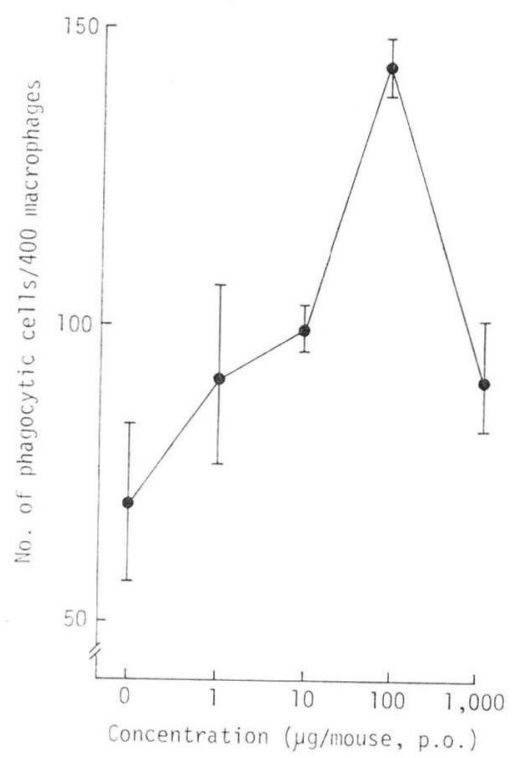

injection of $10^{8} \mathrm{SRBC}$ and given forphenicinol at the time of the immunization. Four days later, antibody formation was determined by enumerating the direct $\mathrm{PFC}$ in spleens. Forphenicinol from $1 \mu \mathrm{g}$ to $1 \mathrm{mg} /$ mouse intraperitoneally or orally did not produce any effect on the number of antibody-forming cells.

\section{Effect of Forphenicinol on Phagocytosis of}

Yeasts by Mouse Peritoneal Macrophages

Mice were injected with thioglycolate broth intraperitoneally, and 3 days later, they were given forphenicinol orally. One day thereafter, macrophage cultures were prepared from peritoneal exudate cells and incubated with yeasts. After the incubation, the number of phagocytic cells was counted by a microscope. Fig. 2 shows that phagocytic activity of macrophages was stimulated by administration of forphenicinol. Although the effect was observed in doses of $1 \mu \mathrm{g}$

to $1 \mathrm{mg} /$ mouse, the maximum stimulation was shown by $100 \mu \mathrm{g} / \mathrm{mouse}$.

Effect of Forphenicinol on Lymphocyte Proliferation with or without Mitogens

The influence of forphenicinol on proliferation of mouse lymphocytes was examined. Forphenicinol was added at from $0.025 \mu \mathrm{g}$ to $100 \mu \mathrm{g} / \mathrm{ml}$ to spleen cell cultures with or without ConA or LPS and incubated for 3 days. After the incubation, incorporation of $\left[{ }^{3} \mathrm{H}\right]$ thymidine into cultured cells was determined. No change in the incorporation was observed due to the addition of forphenicinol to the cultures (Table 4).

Spleen cells were incubated with forphenicinol for 24 hours. After incubation, lymphocytes were collected and cultured for 3 days, and the incorporation of $\left[{ }^{3} \mathrm{H}\right]$ thymidine into cells was determined ${ }^{9)}$. In this system also, forphenicinol produced no effect on lymphocyte proliferation.

Mice were given forphenicinol ( $1 \mu \mathrm{g} \sim 1 \mathrm{mg} / \mathrm{mouse})$ orally. One day later, spleen cells were col-

Table 4. Influence of forphenicinol on blastogenesis of spleen cells.

\begin{tabular}{c|ccc}
\hline $\begin{array}{c}\text { Forphenicinol } \\
(\mu \mathrm{g} / \mathrm{ml})\end{array}$ & Without lectin & $\begin{array}{c}\text { ConA } \\
(\mathrm{cpm} / \mathrm{culture} \pm \mathrm{S} . \mathrm{D} .)\end{array}$ & LPS \\
\hline None & $147 \pm 35$ & $19,305 \pm 312$ & $11,082 \pm 963$ \\
0.025 & $167 \pm 49$ & $19,975 \pm 1,908$ & $10,773 \pm 650$ \\
0.1 & $107 \pm 11$ & $18,317 \pm 1,686$ & $10,857 \pm 1,034$ \\
0.4 & $158 \pm 28$ & $20,974 \pm 1,495$ & $10,600 \pm 840$ \\
1.6 & $124 \pm 14$ & $20,237 \pm 1,468$ & $12,177 \pm 920$ \\
6.2 & $133 \pm 15$ & $20,645 \pm 1,145$ & $12,121 \pm 947$ \\
25 & $130 \pm 14$ & $21,727 \pm 2,322$ & $11,458 \pm 1,304$ \\
100 & $143 \pm 10$ & $19,786 \pm 1,370$ & $11,240 \pm 793$ \\
\hline
\end{tabular}


Table 5. Effect of forphenicinol on the production of CFU-C (granulocytes-macrophages) from mouse bone marrow cells stimulated by LPS-induced colony-stimulating factor (CSF).*

\begin{tabular}{|c|c|c|}
\hline $\begin{array}{l}\text { Forphenicinol } \\
\qquad(\mu \mathrm{g} / \mathrm{ml})\end{array}$ & $\begin{array}{c}1 \% \mathrm{CSF} \\
\text { No. of CFU-C }\end{array}$ & $\begin{array}{c}2 \% \text { CSF } \\
\text { No. of CFU-C }\end{array}$ \\
\hline 10 & $54.3 \pm 3.9 \quad \mathrm{P}<0.05$ & - \\
\hline 1 & $68.0 \pm 1.6 \quad \mathrm{P}<0.01$ & $125.0 \pm 6.4 \quad P<0.05$ \\
\hline 0.1 & $47.3 \pm 6.8 \quad \mathrm{P}<0.05$ & $123.5 \pm 2.1 \quad P<0.05$ \\
\hline 0.01 & $44.0 \pm 5.7$ & $116.0 \pm 12.2 \quad \mathrm{P}<0.05$ \\
\hline 0.001 & $43.0 \pm 3.3$ & $96.3 \pm 13.1$ \\
\hline 0 & $37.0 \pm 0.8$ & $79.7 \pm 12.1$ \\
\hline
\end{tabular}

* Mouse bone marrow cells were suspended in alpha-MEM supplemented with those as described by STANLEY et al. ${ }^{13)}$ and cultured with forphenicinol in the presence of CSF for 10 days at $37^{\circ} \mathrm{C}$ in $10 \%$ $\mathrm{CO}_{2}$. The number of CFU-C was counted.

lected and cultured for 3 days. After 3 days, the incorporation of $\left[{ }^{3} \mathrm{H}\right]$ thymidine was tested. Forphenicinol produced no effect.

Augmentation of CFU-C Production in Mouse Bone Marrow Cell Culture by Forphenicinol

In order to know whether forphenicinol affects bone marrow progenitor cells, we examined the effect of forphenicinol on CFU-C in bone marrow cell cultures. The colonies which are produced in the presence of LPS-induced CSF were known to be granulocytes and macrophages. Table 5 shows that forphenicinol at $1 \mu \mathrm{g} / \mathrm{ml}$ increased the number of CFU-C by $84 \%$ in $1 \%$ CSFmedium and by $57 \%$ in $2 \% \mathrm{CSF}$-medium. The effect of forphenicinol was observed also at 0.1 or $0.01 \mu \mathrm{g} / \mathrm{ml}$. Moreover, $10 \mu \mathrm{g} / \mathrm{ml}$ caused no damage of bone marrow cells.

Prevention of Mitomycin C-Induced Leucopenia in Mice by Forphenicinol

To determine the effect of forphenicinol on leucocytes count in mice to which mitomycin $\mathrm{C}$ was intraperitoneally injected was examined. Mitomycin C $(50 \mu \mathrm{g} /$ mouse, i. p.) was given to mice daily for 5 days with or without forphenicinol and the number of leucocytes in peripheral blood was counted from 1 day after the last administration. The result is shown in Fig. 3. The leucocyte count of mice treated with mitomycin C alone was reduced to about $6,000 \mathrm{~mm}^{3} 1$ or 2 days after the last injection and was further reduced up to the time of death. In the group treated with mitomycin $\mathrm{C}$ and forphenicinol (10 $\mu \mathrm{g} / \mathrm{mouse}$ daily during mitomycin $\mathrm{C}$ treatment) the leucocyte

Fig. 3. Effect of forphenicinol on mitomycin $\mathrm{C}$ induced leucopenia in mice.
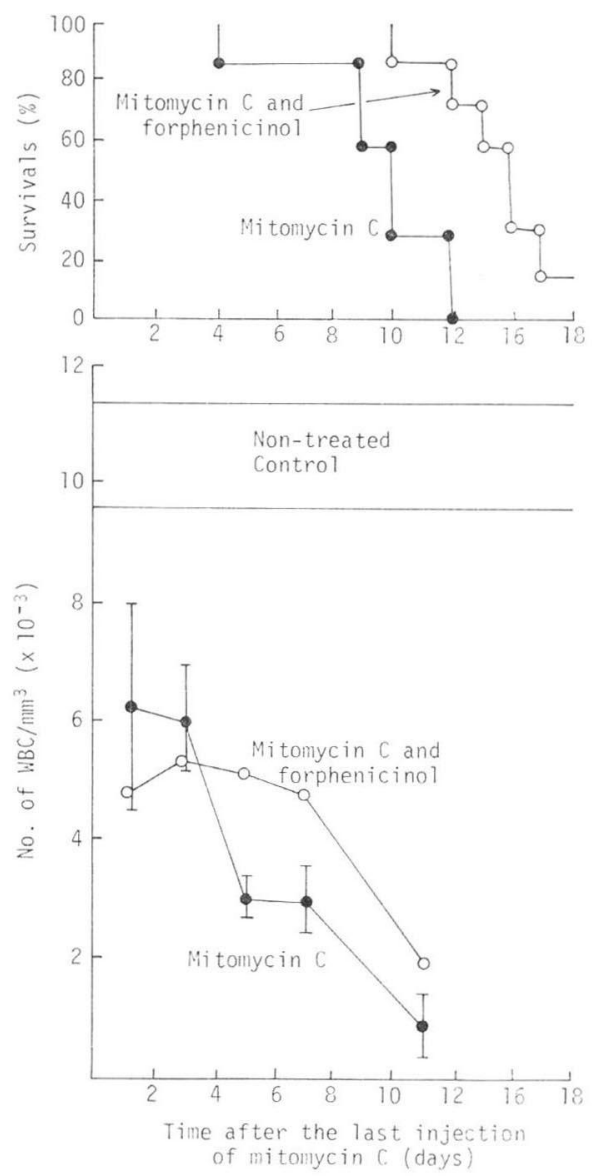
count was also reduced to about $5,000 \mathrm{~mm}^{3} 1$ day after the last administration, but no further decrease was observed up to 7 days. The mitomycin C-treated mice started to die from 4 days and within 9 to 12 days, all mice had died. In comparison, the survival period of mice was prolonged by forphenicinol treatment (Fig. 2).

\section{Discussion}

Forphenicine inhibited chicken intestine alkaline phosphatase strongly and other alkaline phosphatases weakly ${ }^{1}$. The kinetic data were interesting and indicated an uncompetitive inhibition with the substrate. Therefore, we tested the immuno-modifying effect of all derivatives even those which had no activity in inhibiting alkaline phosphatase. Forphenicinol which did not inhibit the enzymes was found to enhance immune responses in mice. A preliminary test using $\left[{ }^{3} \mathrm{H}\right]$-labeled forphenicinol suggested binding to mouse lymphocytes and macrophages.

The establishment of DTH to SRBC and oxazolone was augmented by forphenicinol, especially by oral administration in a wide dose range. Optimum enhancement was observed at from 1 to $100 \mu \mathrm{g} /$ mouse. In mice immuno-suppressed by cyclophosphamide, higher doses such as 10 and $100 \mu \mathrm{g} / \mathrm{mouse}$ were required to restore the reduced DTH. Forphenicinol from $1 \mu \mathrm{g}$ to $1 \mathrm{mg} / \mathrm{mouse}$ did not produce any effect on antibody formation. Thus, forphenicinol was shown to be an immuno-modifier of cellmediated immunity.

Forphenicinol was found to have no effect on lymphocyte proliferation. As reported previously, bestati $^{10)}$ and diketocoriolin $\mathrm{B}^{14)}$ has stimulatory effect on lymphocyte proliferation, and other low molecular weight immuno-modifiers are also known to cause blastogenesis of lymphocytes ${ }^{15,16)}$.

As shown in Fig. 1, being different from bestatin, forphenicinol activated macrophages in vivo and in vitro. This effect suggests that the primary site of augmentation of immune response by forphenicinol might be macrophages. In preliminary experiments, forphenicinol stimulated the production of superoxide anion by macrophages and changed the activities of some enzymes in macrophages.

Besides the enhancement of DTH and macrophage phagocytosis, forphenicinol increased the production of CFU-C in bone marrow cell cultures with CSF. This effect was reflected in the prevention of reduction of the number of leucocytes in animals with leucopenia. As shown in Fig. 2, the treatment with forphenicinol counteracted partially the decrease of leucocyte counts caused by mitomycin $\mathrm{C}$ treatment.

Forphenicine enhanced DTH and increased the number of antibody-forming cells in a wide range of doses given by intraperitoneal administration ${ }^{22}$. Forphenicine also increased CFU-C. Moreover, forphenicine was shown to act on macrophages and increase the number of antibody-forming cells: when lymphocytes or macrophages were treated with forphenicine and cultured with untreated macrophages or lymphocytes, the effect in increasing antibody-forming cells was observed in the reconstituted culture of lymphocytes with macrophage incubated with SRBC and forphenicine. Thus, the minor structural change from forphenicine to forphenicinol eliminated the effect of increasing the number of antibody-forming cells and causing the blastogenesis of peripheral lymphocytes. These observations suggest that further derivative and analog studies around forphenicine should be done.

Forphenicine and forphenicinol have extremely low toxicity. The clinical study has indicated that forphenicinol orally given increases $\mathrm{T}$ cell $\%$ and enhances NK cell activity in cancer patients ${ }^{17)}$.

\section{Acknowledgements}

This work was partly supported by a Grant-in-Aid for Cancer Research from the Ministry of Education, Science and Culture and by a grant from the Ministry of Health and Welfare, Hepatitis Research Committee, Japan, and by a contract from the Division of Cancer Treatment, the National Cancer Institute, NO1-CM-57009. 


\section{References}

1) Umezawa, H.: Small molecular weight immuno-modifiers produced by microorganisms: their screening and discoveries and the genetics of microbial secondary metabolites. Small Molecular in Immuno-modifiers of Microbial Origin - Fundamental and Clinical Studies of Bestatin. Ed. by H. Umezawa, pp. 1, Japan Scientific Societies Press, 1981

2) Aoyagi, T.; T. Yamamoto, K. Kojiri, F. Kojima, M. Hamada, T. Takeuchi \& H. Umezawa: Forphenicine, an inhibitor of alkaline phosphatase produced by actinomycetes. J. Antibiotics 31: 244 246, 1978

3) Yamamoto, T.; K. Kojiri, H. Morishima, H. Naganawa, T. Aoyagi \& H. Umezawa: The structure of forphenicine. J. Antibiotics 31: 483 484, 1978

4) Ishizuka, M.; T. Masuda, N. Kanbayashi, Y. Watanabe, M. Matsuzaki, Y. Sawazaki, A. Ohkura, T. TAKEUCHI \& H. UMEZAWA: Antitumor effect of forphenicinol, a low molecular weight immunomodifier, on murine transplantable tumors and microbial infections. J. Antibiotics 35: 1049 1054, 1982

5) Morishima, H. et al.: Synthesis of L-forphenicinol and forphenicine. in preparation.

6) Ishizuka, M.; T. Masuda, N. Kanbayashi, S. Fukasawa, T. Takeuchi, T. Aoyagi \& H. Umezawa: Effect of bestatin on mouse immune system and experimental murine tumors. J. Antibiotics 33: 642 652, 1980

7) JeRne, N. I.; A. A. NORDIn \& C. HENRY: "The agar plaque technique for recognizing antibody-producing cells" in cell-bound antibodies. pp. $109 \sim 122$, Wistar Institute Press, Philadelphia, 1963

8) Cunningham, A. J. \& A. Szenberg: Further improvements in the plaque technique for detecting single antibody-forming cells. Immunology 14: 599 600, 1968

9) Ishizuka, M.; J. Sato, Y. Sugryama, T. Takeuchi \& H. Umezawa: Mitogenic effect of bestatin on lymphocytes. J. Antibiotics 33: 653 662, 1980

10) Ishizuka, M.; T. Aoyagi, T. TAKeuchi \& H. Umezawa: Activity of bestatin: Enhancement of immune responses and antitumor effect. Small Molecular Immunomodifiers of Microbial Origin - Fundamental and Clinical Studies of Bestatin, Ed. by H. Umezawa, pp. 17, Japan Scientific Societies Press, 1981

11) Ishizuka, M.; S. Fukasawa, T. Masuda, J. Sato, N. Kanbayashi, T. Takeuchi \& H. Umezawa: Antitumor effect of bactobolin and its influence on mouse immune system and hematopoietic cells. J. Antibiotics 33: $1054 \sim 1062,1980$

12) Metcalf, D.: Acute-antigen elevation of serum colony stimulating factor (CSF) levels. Immunology 21 : $427 \sim 436,1971$

13) Stanley, E. R.; M. Cifone, P. M. Heard \& V. Deffendi: Factors regulating macrophage production and growth: Identity of colony stimulating factor and macrophage growth factor. J. Exp. Med. 143: 631 647,1976

14) Ishizuka, M.; T. TAKeuchi \& H. Umezawa: Studies on the mechanism of action of diketocoriolin B to enhance antibody formation. J. Antibiotics 34: 95 102, 1981

15) Hadden, J. W.; R. G. Coffey, E. M. Hadden, E. Lopez-Corrales \& G. H. Sunshine: Effect of levamisole and imidazole on lymphocyte proliferation and cyclic nucleotide levels. Cell. Immunol. 20: 98 103, 1975

16) Graber, C. D.; J. M. Goust, A. D. Glassman, R. Kendall \& C. B. Loadholt: Immunomodulating properties of dimethylglycine in humans. J. Infectious Dis. 143: 101 105, 1981

17) Kumano, N.; Y. Nakai, S. Takizawa, K. Oizumi \& K. Konno: Preliminary phase I study of forphenicinol - Changes in T and B lymphocytes population. Proceeding of the Japanese Cancer Association. The 40th Annual Meeting, No. 889, 1981 